\title{
PEMANTAUAN KANDUNGAN LOGAM BERAT Pb DAN Cd PADA SEDIMEN DI PESISIR TELUK AMBON DALAM SEBAGAI INDIKASI TINGKAT PENCEMARAN
}

\section{MONITORING OF Pb AND Cd HEAVY METAL CONTENT ON SEDIMENT IN INNER AMBON BAY COASTAL AS INDICATION OF POLLUTION LEVEL}

\author{
Ignacius D. Sukaryono dan Riardi P. Dewa \\ Balai Riset dan Standardisasi Industri Ambon Jalan Kebun Cengkeh Ambon 97128 \\ Email : dhaniigna@yahoo.com
}

Received : 29/12/2017; revised : 03/15/2018; accepted : 04/07/2018

Published online : 31/07/2018

\begin{abstract}
ABSTRAK
Pesisir Teluk Ambon Dalam merupakan konsentrasi segala macam aktivitas sebagian besar masyarakat Kota Ambon. Aktivitas tersebut sebagian besar memanfaatkan sumber daya yang ada di sekitar wilayah pesisir baik sumber daya alam maupun sumber daya yang bukan berasal dari alam. Pemanfaatan ini sering kali menghasilkan limbah yang salah satunya berupa limbah logam berat yang dapat mengkontaminasi lingkungan sekitar pesisir. Salah satu yang terjadi adalah kontaminasi logam berat pada sedimen. Penelitian ini menelusuri jejak kontaminan logam berat jenis $\mathrm{Pb}$ dan $\mathrm{Cd}$ pada sedimen dengan lokasi pengambilan sampel di 10 lokasi di sepanjang Teluk Ambon Dalam dengan jangka waktu pengambilan sampel sebanyak 2 kali dalam tahun 2016. Sampel sedimen dilakukan pengujian kandungan logam berat dengan menggunakan alat AAS-Flame. Tujuan dari penelitian ini adalah untuk mengetahui tingkat pencemaran sedimen oleh logam berat $\mathrm{Pb}$ dan $\mathrm{Cd}$ sebagai indikator kualitas lingkungan. Hasil penelitian menunjukkan bahwa sedimen di pesisir Teluk Ambon Dalam menurut nilai Faktor Kontaminasi (CF) termasuk kategori tingkat kontaminasi rendah $(\mathrm{CF}<1)$ dan menurut nilai Indeks Geoakumulasi (I-Geo) termasuk kategori tidak tercemar (I-Geo < 0) untuk masing-masing logam berat dan waktu pengambilan sampel. Sedangkan menurut Indeks Beban Pencemaran (PLI) tergolong ke dalam kategori tidak tercemar sampai tercemar ringan $(0<\mathrm{PLI}<2)$.
\end{abstract}

Kata kunci : sedimen, logam berat, pesisir, tingkat pencemaran

\begin{abstract}
Inner Ambon Bay Coastal is all kinds activities concentration of Ambon City citizen. These activities mostly utilize the resources that exist around the coastal areas of both natural resources and non-natural resources. This utilization often produces waste, one of them is heavy metal waste. It can contaminate environment around the coastal. One of things that happens is heavy metal contamination in sediment. This research search traces of heavy metal contaminants of $\mathrm{Pb}$ and $\mathrm{Cd}$ types in sediments with sampling sites at 10 locations along Inner Ambon Bay and sampling period of 2 times in 2016. Sediment samples were tested for heavy metal content using AAS-Flame. This research purpose is to determine the level of sediment pollution by heavy metals $\mathrm{Pb}$ and $\mathrm{Cd}$ as an indicator of environmental quality. The results showed that the sediments on the coast of Inner Ambon Bay according to the value of Contamination Factor (CF) include low contamination level category $(C F<1)$ and according to Geoaccumulation Index value (I-Geo) including uncontaminated category (I-Geo <0) for each heavy metal and sampling time. Meanwhile, according to the Pollution Load Index (PLI) belong to the category not contaminated until lightly contaminated $(0<P L I<2)$.
\end{abstract}

Key words : sediment, heavy metal, coastal, level of pollution

\section{PENDAHULUAN}

Indonesia sebagai salah satu negara kepulauan yang terbesar di dunia, wilayah pesisir mempunyai peranan dan fungsi yang sangat utama dan penting. Banyak aktivitas yang dilakukan manusia berada disekitar wilayah pesisir. Aktivitas tersebut antara lain aktivitas industri, transportasi laut, pariwisata atau rekreasi, dan aktivitas-aktivitas lainnya yang berhubungan dengan pemenuhan kebutuhan hidup dari manusia itu sendiri. Aktivitas-aktivitas tersebut sebagian besar memanfaatkan sumber daya alam yang terdapat di sekitar wilayah pesisir seperti air laut, air payau, tanaman dan binatang yang hidup di sekitar wilayah pesisir. 
Pulau Ambon merupakan salah satu pulau yang berada di kepulauan Maluku dan menjadi letak dari ibukota Provinsi Maluku, Kota Ambon. Lebih dari setengah luas Pulau Ambon menjadi wilayah adminitrasi dari Kota Ambon. Kota Ambon mempunyai luas sekitar $786 \mathrm{~km}^{2}$ yang sekitar $52 \%$ berupa perairan dengan garis pantai sekitar $102 \mathrm{~km}$. Perairan yang dimaksud berupa teluk yang disebut dengan Teluk Ambon. Teluk Ambon terdiri dari dua, Teluk Ambon Luar dan Teluk Ambon Dalam, yang menjadi batas imajinernya berupa Jembatan Merah Putih. Teluk Ambon merupakan pusat aktivitas sebagian besar warga Kota Ambon. Aktivitas yang ada di sekitar pesisir Teluk Ambon Luar antara lain perikanan tangkap, pasar, transportasi laut, wisata air, industri kecil dan menengah, industri besar, pelabuhan, cold storage dan perumahan. Sedangkan aktivitas di sekitar pesisir Teluk Ambon Dalam antara lain perikanan budidaya, perumahan, transportasi laut, wisata air, konservasi mangrove, industri kecil dan menengah, pangkalan TNI AL dan PLTD (Ohello 2010).

Aktivitas yang dilakukan di sekitar wilayah pesisir potensial menghasilkan produk samping berupa limbah dalam bentuk padat (sampah) dan limbah cair. Selain itu, aktivitas di wilayah pesisir tersebut dapat menyebabkan perubahan ekosistem pesisir dan lautan yang dapat berlanjut pada kerusakan ekosistem pesisir dan lautan. Kontaminasi logam berat merupakan salah satu dari dampak adanya limbah. Kandungan logam berat di wilayah pesisir dapat ditemukan pada sedimen, air laut, hewan dan tumbuhan yang hidup disekitar wilayah pesisir. Menurut penelitian Permanawati, dkk (2013) dan Rochyatun \& Kaisupy (2006), kadar logam berat pada sedimen permukaan lebih tinggi dibandingkan dengan air laut. Hal tersebut dikarenakan adanya proses pengendapan sehingga terjadi akumulasi logam berat dalam sedimen. Kandungan logam berat pada hewan dan tumbuhan yang hidup di sekitar wilayah pesisir tergantung pada jenis hewan dan tumbuhan itu sendiri, selain itu juga tergantung jenis logam beratnya.

Kandungan logam berat pada sedimen di sekitar wilayah pesisir dapat dijadikan sebagai indikator tingkat pencemaran suatu lingkungan. Pengindikasian ini didapatkan dengan menggunakan suatu perangkat analisis atau metode. Metode yang biasa digunakan untuk menilai kualitas lingkungan berbasis kandungan logam berat dalam sedimen antara lain Faktor Kontaminasi (CF/Contamination Factor), Indeks Beban Pencemaran (PLI/Pollution Load Index) dan Indeks Geoakumulasi (IGeo/Geoaccumulation Index) (Ahmad 2013).
Beberapa penelitian tentang penilaian kualitas lingkungan berbasis data kandungan logam berat dalam sampel sedimen telah banyak dilakukan. Penelitian-penelitian tersebut digunakan sebagai salah satu cara asesmen kualitas lingkungan khususnya di daerah perairan atau pesisir. Menurut Edward (2014) yang melakukan penelitian kandungan logam berat jenis $\mathrm{Pb}, \mathrm{Cd}, \mathrm{Cu}, \mathrm{Zn}$ dan $\mathrm{Ni}$ dalam sedimen di Teluk Wawobatu, Kendari, hasilnya menunjukkan bahwa berdasarkan nilai PLI, sedimen di lokasi sampling termasuk kategori tidak tercemar dan belum berbahaya untuk kehidupan biota laut yang mencari makan dalam sedimen $(\mathrm{PLI}<1)$. Berdasarkan nilai $\mathrm{I}-\mathrm{Geo}$, sedimen di perairan lokasi sampling termasuk kategori tercemar sedang oleh $\mathrm{Cd}(0<\mathrm{I}-\mathrm{Geo}<$ 2) dan tidak tercemar oleh $\mathrm{Pb}, \mathrm{Cu}, \mathrm{Zn}$ dan $\mathrm{Ni}$ (IGeo $<0$ ).

Mulyaningsih, dkk (2012) telah menerangkan bahwa nilai PLI dalam sedimen di DAS Ciujung Banten belum terkontaminasi oleh logam berat jenis $\mathrm{As}, \mathrm{Cr}, \mathrm{Sb}, \mathrm{Zn}, \mathrm{Pb}, \mathrm{Cd}, \mathrm{Cu}, \mathrm{Ni}$, $\mathrm{Co}, \mathrm{Mn}$ dan Fe. Sedangkan berdasarkan nilai IGeo, sedimen di lokasi sampling dengan kondisi belum terkontaminasi hingga kontaminasi sedang oleh logam $\mathrm{Pb}, \mathrm{Cr}, \mathrm{Cu}, \mathrm{Zn}$, Co, As, Sb, $\mathrm{Mn}$ dan Fe. Penelitian yang dilakukan Edward (2015), tentang penilaian tingkat pencemaran logam berat jenis $\mathrm{Pb}, \mathrm{Cd}, \mathrm{Cu}, \mathrm{Zn}, \mathrm{Ni}$, dan $\mathrm{Cr}$ dalam sedimen di perairan Pulau Morotai, Maluku Utara menggambarkan bahwa berdasarkan nilai CF, PLI dan I-Geo, sedimen di perairan Pulau Morotai termasuk dalam kondisi belum terkontaminasi oleh logam $\mathrm{Pb}, \mathrm{Cd}, \mathrm{Cu}$, $\mathrm{Zn}$, Ni dan $\mathrm{Cr}(\mathrm{CF}<0$; I-Geo < 0; $\mathrm{PLI}<1)$.

Dalam penelitian ini dipilih 2 (dua) jenis logam berat yang akan dianalisa kandungannya di sampel sedimen yaitu $\mathrm{Cd}$ dan $\mathrm{Pb}$. Logam $\mathrm{Cd}$ diperairan akan mengendap dan terakumulatif pada suatu jaringan organisme yang sulit terurai karena senyawa sulfitnya sukar larut. Logam Cd bersumber dari guangan limbah pabrik, aktivitas kapal dan endapan sampah anorganik. Logam $\mathrm{Pb}$ banyak dijumpai dan digunakan dalam berbagai aktivitas manusia. Cemaran logam $\mathrm{Pb}$ bersumber pada buangan sejumlah industri dan buangan dari bahan bakar kendaraan bermotor serta sampah plastik yang mengandung logam $\mathrm{Pb}$. Logam $\mathrm{Pb}$ yang berasal dari buangan hasil samping pembakaran bahan bakar kendaraan bermotor selanjutnya dapat masuk ke badan air atau perairan di sekitar sumber polusinya. Di perairan, sumber logam $\mathrm{Pb}$ juga berasal dari batuan kapur. Dari hal-hal tersebut yang dijadikan alasan dipilihnya 2 (dua) jenis logam berat yang akan dianalisa kandungannya dalam sedimen.

Tujuan dari penelitian ini adalah untuk mengetahui tingkat pencemaran atau kualitas 
lingkungan pesisir di Teluk Ambon Dalam berbasis kandungan logam berat jenis Timbal $(\mathrm{Pb})$ dan Kadmium $(\mathrm{Cd})$ dalam sedimen dengan menggunakan perangkat analisis. Selain itu juga diharapkan hasilnya dapat dijadikan referensi kualitas lingkungan pesisir di Teluk Ambon Dalam sehingga dapat dijadikan acuan dalam pelaksanaan pengembangan ekonomi berbasis perairan atau pesisir.

\section{METODE PENELITIAN}

\section{Alat dan Bahan}

Alat yang digunakan dalam penelitian ini adalah AAS-Flame 7000 Shimadzu; pipet ukur $10 \mathrm{ml}$; labu ukur 50, 100 dan $1000 \mathrm{ml}$; gelas piala $100 \mathrm{ml}$; timbangan analitik; cawan porselin; desikator; oven; gelas ukur $100 \mathrm{ml}$; pipet volumetrik 1, 2, 3, 4, 5, dan $10 \mathrm{ml}$; hot plate Lab Tech; corong; kaca arloji; batang pengaduk; spatula; mortar dan alu; Erlenmeyer $250 \mathrm{ml}$. Bahan yang digunakan adalah air suling bebas logam; asam nitrat $\mathrm{HNO}_{3}$ p.a; larutan induk Timbal dan Kadmium 1000 mg/l; asam perklorat $\mathrm{HClO}_{4}$ p.a; kertas saring dan sampel sedimen.

\section{Cara Kerja}

Langkah pertama dalam melakukan penelitian ini adalah melakukan sampling sedimen yang akan dijadikan objek dalam penelitian ini. Sedimen diambil di sekitar wilayah pesisir Teluk Ambon Dalam dengan 10 stasiun atau lokasi pengambilan sampel sedimen. Adapun kesepuluh stasiun atau lokasi pengambilan sampel adalah Galala, Halong, Latta, Lateri, Passo, Negeri Lama, Nania, Waiheru, Hunuth, dan Poka. Sedimen yang diambil berupa campuran pasir, tanah dan batu karang. Setelah dilakukan proses sampling sedimen, tahapan selanjutnya adalah pengujian atau analisa laboratorium terhadap kandungan logam berat Timbal $(\mathrm{Pb})$ dan Kadmium (Cd).
Pengukuran kandungan logam berat digunakan metode standar SNI 06-6992.3-2004 (Cara uji Timbal (Pb)) (BSN 2004a) dan SNI 06-6992.42004 (Cara uji Kadmium (Cd)) (BSN 2004b).

\section{Analisis Data}

Setelah dilakukan tahapan pengujian dan didapatkan hasil uji, maka langkah selanjutnya adalah menganalisa data hasil pengujian ke dalam proses penilaian kualitas lingkungan berbasis data hasil kandungan logam berat dalam sedimen. Parameter-parameter yang dipakai dalam analisa data penelitian ini yaitu Faktor Kontaminasi (CF), Indeks Beban Pencemaran (PLI) dan Indeks Geoakumulasi (IGeo).

Faktor Kontaminasi (CF) dapat digunakan untuk menerangkan proses kontaminasi yang diberikan bahan toksik terhadap lingkungan, persamaannya sebagai berikut :

$\mathrm{CF}=\mathrm{C}_{\mathrm{X}} / \mathrm{C}_{\text {Background }}\left(\mathrm{B}_{\mathrm{n}}\right)$

(pers. 1)

dengan $C_{X}$ adalah konsentrasi logam $X$ dalam sampel sedimen yang diteliti; $\mathrm{C}_{\text {Background }}\left(\mathrm{B}_{\mathrm{n}}\right)$ adalah konsentrasi rerata normal logam $X$ di alam (Wardhani dkk 2016). Konsentrasi rerata normal untuk logam $\mathrm{Pb}$ adalah $20 \mathrm{ppm}$ dan untuk logam $\mathrm{Cd}$ adalah 0,3 ppm (Odat and Alshammari 2011).

Indeks Beban Pencemaran (PLI) dapat digunakan sebagai cara sederhana untuk memperkirakan status kontaminan. Formulasi yang digunakan untuk menghitung Indeks Beban Pencemaran (PLI) adalah sebagai berikut :

$$
\mathrm{PLI}=\left[\mathrm{CF}_{1} \times \mathrm{CF}_{2} \times \mathrm{CF}_{3} \ldots . . \times \mathrm{CF}_{\mathrm{n}}\right]^{1 / \mathrm{n}} \text {; (pers. 2) }
$$

CF adalah factor kontaminasi; $\mathrm{n}=$ jumlah logam (Mohiuddin et al. 2011).

Tabel 1. Kriteria Tingkat Pencemaran dan Kontaminasi (Ahmad, 2013)

\begin{tabular}{|c|c|c|}
\hline Faktor kontaminasi (CF) & $\begin{array}{l}\begin{array}{l}\text { Indeks Beban } \\
\text { (PLI) }\end{array} \\
\text { (Pencemaran }\end{array}$ & Indeks Geoakumulasi (I-Geo) \\
\hline $\begin{array}{l}\mathrm{CF}<1 \\
\text { Tingkat kontaminasi rendah } \\
1<\mathrm{CF}<3 \\
\text { Tingkat kontaminasi sedang }\end{array}$ & $\begin{array}{l}<0 \\
\text { Tidak tercemar } \\
0-2 \quad \\
\text { Tidak tercemar } \\
\text { tercemar ringan }\end{array}$ & $\begin{array}{l}\text { I-Geo }<0 \\
\text { Tidak tercemar } \\
0<\mathrm{I}-\mathrm{Geo}<1 \\
\text { Tercemar ringan }\end{array}$ \\
\hline $\begin{array}{l}3<\mathrm{CF}<6 \\
\text { Tingkat kontaminasi cukup }\end{array}$ & $\begin{array}{l}2-4 \\
\text { Tercemar sedang }\end{array}$ & $\begin{array}{l}1<1-\text { Geo }<2 \\
\text { Tercemar sedang }\end{array}$ \\
\hline $\begin{array}{l}\text { CF }>6 \\
\text { Tingkat kontaminasi sangat tinggi }\end{array}$ & $\begin{array}{l}4-6 \\
\text { Tercemar parah } \\
6-8 \\
\text { Tercemar sangat parah } \\
8-10 \\
\text { Tercemar luar biasa parah }\end{array}$ & $\begin{array}{l}2<\mathrm{I}-\mathrm{Geo}<3 \\
\text { Tercemar cukup parah } \\
3<\mathrm{I}-\mathrm{Geo}<4 \\
\text { Tercemar parah } \\
4<\mathrm{I}-\mathrm{Geo}<5 \\
\text { Tercemar luar biasa parah } \\
\text { I-Geo }>5 \\
\text { Tercemar sangat luar biasa parah }\end{array}$ \\
\hline
\end{tabular}


Indeks Geoakumulasi (I-Geo) dapat menggambarkan pengkayaan konsentrasi logam berat diatas baseline level atau tingkatan nilai dasar. Formulasi untuk menghitung Indeks Geoakumulasi (I-Geo) adalah sebagai berikut :

I-Geo $=\log 2\left(C_{X} /\left(1,5 C_{\text {Background }}\left(B_{n}\right)\right)\right) ; \quad($ pers. 3)

dengan $C_{X}$ adalah konsentrasi logam $X$ dalam sampel sedimen yang diteliti; $C_{B a c k g r o u n d}\left(B_{n}\right)$ adalah konsentrasi rerata normal logam $X$ di alam; 1,5 adalah konstanta (Ahmad 2013).

Untuk kriteria tingkat pencemaran dan kontaminasi untuk masing-masing parameter disajikan dalam tabel1.

\section{HASIL DAN PEMBAHASAN}

Hasil pengujian kandungan logam berat Timbal $(\mathrm{Pb})$ dan Kadmium (Cd) di dalam sedimen dan perhitungan nilai Faktor Kontaminasi $(C F)$, Indeks Beban Pencemaran $(P L I)$ dan Indeks Geoakumulasi ( $I$-Geo) disajikan dalam Tabel 2 untuk pengambilan sampel bulan Mei 2016 dan Tabel 3 untuk pengambilan sampel bulan Desember 2016 dibawah ini.

Tabel 2 diatas menunjukkan nilai kadar logam $\mathrm{Pb}$ dan $\mathrm{Cd}$; nilai CF, I-Geo dan PLI untuk sampel sedimen yang diambil datanya pada bulan Mei 2016. Kadar $\mathrm{Pb}$ dalam sedimen berkisar antara $0,1300-0,7484 \mathrm{ppm}$ dengan rata-rata 0,3658 ppm dan kadar $\mathrm{Cd}$-nya berkisar antara 0,0108 - 0,0171 ppm dengan rata-rata 0,0140 ppm. Kadar kedua logam berat tersebut masih dibawah nilai ambang batas menurut Standar Mutu Sedimen WAC 173-204-320 yaitu sebesar 450 ppm untuk $\mathrm{Pb}$ dan 5,1 ppm untuk
Cd (Permanawati, dkk 2013). Kadar kedua logam berat tersebut juga tidak melebihi nilai ambang batas yang ditetapkan oleh Canadian Sediment Quality Guidelines for The Protection of Aquatic Life Summary Table yaitu sebesar 35 ppm untuk $\mathrm{Pb}$ dan 0,6 ppm untuk $\mathrm{Cd}$ (CCME 2001). Nilai kadar logam $\mathrm{Pb}$ dan $\mathrm{Cd}$ dalam sedimen hasil sampling juga masih di bawah nilai kadar rerata normal logam berat di alam yaitu sebesar $20 \mathrm{ppm}$ untuk logam $\mathrm{Pb}$ dan 0,3 ppm untuk logam $\mathrm{Cd}$.

Kadar $\mathrm{Pb}$ terbesar dalam sedimen dengan lokasi pengambilan sampel di Hunuth yaitu sebesar $0,7484 \mathrm{ppm}$ dan kadar terkecil dalam sedimen dengan lokasi pengambilan sampel di Negeri Lama. Untuk kadar Cd yang terbesar yaitu dalam sedimen dengan lokasi pengambilan sampel di Galala sebesar 0,0171 ppm dan yang terkecil dalam sedimen dengan lokasi pengambilan sampel di Poka yaitu sebesar $0,0108 \mathrm{ppm}$. Nilai kadar logam berat tersebut bersifat acak menurut lokasi pengambilan sampel, hal ini dapat dikarenakan oleh sangat bervariasinya aktivitas yang terjadi di wilayah pesisir di masing-masing lokasi pengambilan sampel.

Nilai Faktor Kontaminasi (CF) untuk logam $\mathrm{Pb}$ berkisar antara 0,0065 - 0,0374 dengan rata-rata 0,0183 . Nilai tersebut termasuk kategori tingkat kontaminasi rendah $(\mathrm{CF}<1)$ atau bisa dikatakan tidak tercemar oleh logam berat $\mathrm{Pb}$. Hal yang sama juga terjadi pada nilai CF untuk logam Cd yang berkisar antara 0,0360 $-0,0570$ dengan rata-rata 0,0467 .

Tabel 2. Kadar, Faktor Kontaminasi (CF), Indeks Geoakumulasi (I-Geo), dan Indeks Beban Pencemaran (PLI) pengambilan sampel bulan Mei 2016

\begin{tabular}{lccccccc}
\hline \multirow{2}{*}{ LOKASI } & \multicolumn{3}{c}{ TIMBAL (Pb) } & \multicolumn{5}{c}{ KADMIUM (Cd) } & \multirow{2}{*}{$\begin{array}{c}\text { KADAR } \\
\text { (ppm) }\end{array}$} & CF & I-Geo & $\begin{array}{c}\text { KADAR } \\
\text { (ppm) }\end{array}$ & CF & I-Geo & \\
\hline Galala & 0,3850 & 0,0193 & $-6,2840$ & 0,0171 & 0,0570 & $-4,7179$ & 0,0331 \\
Halong & 0,3300 & 0,0165 & $-6,5064$ & 0,0144 & 0,0480 & $-4,9658$ & 0,0281 \\
Latta & 0,3350 & 0,0168 & $-6,4847$ & 0,0163 & 0,0543 & $-4,7870$ & 0,0302 \\
Lateri & 0,2300 & 0,0115 & $-7,0272$ & 0,0116 & 0,0387 & $-5,2777$ & 0,0211 \\
Passo & 0,2350 & 0,0118 & $-6,9962$ & 0,0120 & 0,0400 & $-5,2288$ & 0,0217 \\
Negeri & 0,1300 & 0,0065 & $-7,8503$ & 0,0146 & 0,0487 & $-4,9459$ & 0,0178 \\
Lama & 0,1600 & 0,0080 & $-7,5507$ & 0,0154 & 0,0513 & $-4,8689$ & 0,0203 \\
Nania & 0,5748 & 0,0287 & $-5,7058$ & 0,0116 & 0,0387 & $-5,2777$ & 0,0333 \\
Waiheru & 0,7484 & 0,0374 & $-5,3250$ & 0,0163 & 0,0543 & $-4,7870$ & 0,0451 \\
Hunuth & 0,5300 & 0,0265 & $-5,8228$ & 0,0108 & 0,0360 & $-5,3808$ & 0,0309 \\
Poka & & & & & & & \\
Min & 0,1300 & 0,0065 & $-7,8503$ & 0,0108 & 0,0360 & $-5,3808$ & 0,0178 \\
Max & 0,7484 & 0,0374 & $-5,3250$ & 0,0171 & 0,0570 & $-4,7179$ & 0,0451 \\
Rerata & 0,3658 & 0,0183 & $-6,5553$ & 0,0140 & 0,0467 & $-5,0238$ & 0,0282 \\
SD & 0,1981 & 0,0099 & 0,8123 & 0,0023 & 0,0077 & 0,2444 & 0,0082 \\
\hline
\end{tabular}


Tabel 3. Kadar, Faktor Kontaminasi (CF), Indeks Geoakumulasi (I-Geo), dan Indeks Beban Pencemaran (PLI) pengambilan sampel bulan Desember 2016

\begin{tabular}{lccccccc}
\hline LOKASI & \multicolumn{3}{c}{ TIMBAL (Pb) } & \multicolumn{5}{c}{ KADMIUM (Cd) } & \multirow{2}{*}{ PLI } \\
\cline { 2 - 6 } & $\begin{array}{l}\text { KADAR } \\
\text { Gpmala }\end{array}$ & CF & I-Geo & $\begin{array}{c}\text { KADAR } \\
\text { (ppm) }\end{array}$ & CF & I-Geo & \\
\hline Halong & 0,6700 & 0,0335 & $-5,4847$ & 0,0112 & 0,0373 & $-5,3284$ & 0,0354 \\
Latta & 0,5650 & 0,0283 & $-5,7306$ & 0,0108 & 0,0360 & $-5,3808$ & 0,0319 \\
Lateri & 0,4150 & 0,0208 & $-6,1757$ & 0,0129 & 0,0430 & $-5,1245$ & 0,0299 \\
Passo & 0,4000 & 0,0200 & $-6,2288$ & 0,0103 & 0,0343 & $-5,4492$ & 0,0262 \\
Negeri & 0,4100 & 0,0205 & $-6,1932$ & 0,0106 & 0,0353 & $-5,4078$ & 0,0269 \\
Lama & 0,2900 & 0,0145 & $-6,6928$ & 0,0114 & 0,0380 & $-5,3028$ & 0,0235 \\
Nania & 0,5700 & 0,0285 & $-5,7179$ & 0,0102 & 0,0340 & $-5,4633$ & 0,0311 \\
Waiheru & 0,8400 & 0,0420 & $-5,1584$ & 0,0110 & 0,0367 & $-5,3543$ & 0,0392 \\
Hunuth & 0,8200 & 0,0410 & $-5,1932$ & 0,0120 & 0,0400 & $-5,2288$ & 0,0405 \\
Poka & 0,8400 & 0,0420 & $-5,1584$ & 0,0117 & 0,0392 & $-5,2653$ & 0,0405 \\
Min & & & & & & & \\
Max & 0,2900 & 0,0145 & $-6,6928$ & 0,0102 & 0,0340 & $-5,4633$ & 0,0235 \\
Rerata & 0,8400 & 0,0420 & $-5,1584$ & 0,0129 & 0,0430 & $-5,1245$ & 0,0405 \\
SD & 0,5820 & 0,0291 & $-5,7734$ & 0,0112 & 0,0374 & $-5,3305$ & 0,0325 \\
\hline & 0,2038 & 0,0102 & 0,5346 & 0,0008 & 0,0028 & 0,1047 & 0,0062 \\
\hline
\end{tabular}

Jika dilihat dari parameter I-Geo juga menunjukkan hal yang sama. Sedimen di semua lokasi pengambilan sampel termasuk ke dalam kondisi tidak tercemar oleh logam $\mathrm{Pb}$ dan $\mathrm{Cd}(\mathrm{I}-$ Geo < 0). Nilai CF dan I-Geo ini memiliki perilaku yang sama, hal ini dapat dilihat dari formulasi perhitungan untuk mendapatkan nilai CF dan I-Geo pada pers. 1 dan pers. 3 diatas. Kedua persamaan tersebut terdiri dari 2 variabel yang sama yaitu konsentrasi atau kadar logam tertentu dalam sampel dan kadar logam tertentu rerata normalnya di alam.

Nilai Indeks Beban Pencemaran (PLI) didapatkan dengan mengkalikan nilai $\mathrm{CF}$ pada kedua logam berat $\mathrm{Pb}$ dan $\mathrm{Cd}$ pada masingmasing lokasi pengambilan sampel dan mempangkatkan dengan 1 per $\mathrm{n}$ jumlah logam yang dalam penelitian ini memakai 2 jenis logam. Hasil dari perhitungan didapatkan nilai dengan kisaran antara 0,0178-0,0451 dengan rata-rata 0,0282 . Nilai tersebut termasuk dalam kategori tidak tercemar - tercemar ringan $(0<$ PLI < 2). Hal tersebut menunjukkan bahwa sedimen di kesepuluh lokasi pengambilan sampel belum tercemar oleh logam berat $\mathrm{Pb}$ dan $\mathrm{Cd}$, sehingga masih aman untuk lingkungan sekitarnya.

Kesepuluh lokasi pengambilan sampel mempunyai karakter aktivitas makhluk hidup yang bermukim di sekitar lokasi pengambilan sampel yang hamper sama. Lokasi-lokasi tersebut sebagian besar menjadi konsentrasi kegiatan domestik seperti perumahan dan usaha kegiatan masyarakat lainnya seperti perekonomian, perdagangan dan rekreasi. Oleh sebab itu hasil kadar logam $\mathrm{Pb}$ dan $\mathrm{Cd}$ tidak mempunyai perbedaan yang signifikan, semuanya dalam rentang batas aman dan tidak berbahaya. Tabel 3 diatas sama halnya dengan tabel 2 yaitu menggambarkan nilai kadar logam berat $\mathrm{Pb}$ dan $\mathrm{Cd}$ sampel sedimen, faktor kontaminasi (CF), indeks geoakumulasi (I-Geo) dan indeks beban pencemaran (PLI) untuk masing-masing sedimen berdasarkan lokasi pengambilan sampel dengan waktu pengambilan sampel pada bulan Desember 2016. Nilai konsentrasi logam berat $\mathrm{Pb}$ sedimen pada pengambilan sampel bulan Desember 2016 ini menunjukkan kenaikan dari pada konsentrasi logam berat $\mathrm{Pb}$ sedimen pada pengambilan sampel bulan Mei 2016. Nilainya berkisar antara 0,2900-0,8400 ppm dengan rata-rata $0,5820 \mathrm{ppm}$. Hal yang berbeda terjadi pada kadar logam berat $\mathrm{Cd}$ sedimen. Konsentrasi logam berat $\mathrm{Cd}$ sedimen pada pengambilan sampel bulan Desember 2016 lebih kecil dari pada bulan Mei 2016 yaitu berkisar antara 0,0102 - 0,0129 ppm dengan rata-rata 0,0112 ppm. Akumulasi logam berat pada sedimen dipengaruhi oleh beberapa faktor seperti suhu, tingkat garam, $\mathrm{pH}$, reaksi reduksi oksidasi, bahan organic, padatan terlarut, aktivitas biologi dan sifat dasar logam itu sendiri (Ismarti, Amelia, and Ramses 2015).

Kadar logam berat $\mathrm{Pb}$ dan $\mathrm{Cd}$ pada sedimen dengan pengambilan sampel bulan Desember 2016 masih dibawah nilai ambang batas dari standar yang ditetapkan oleh Standar Mutu Sedimen WAC 173-204-320 maupun Canadian Sediment Quality Guidelines for The Protection of Aquatic Life Summary Table. Hal tersebut mengindikasi bahwa sedimen di sekitar pesisir lokasi pengambilan sampel belum mengalami pencemaran jika dilihat dari segi nilai kadar logam berat dalam sedimen. Dengan kata lain, sedimen di sekitar pesisir Teluk Ambon Dalam berstatus aman oleh kontaminasi logam berat $\mathrm{Pb}$ dan $\mathrm{Cd}$.

Nilai CF dan I-Geo memiliki kategori yang sama dengan nilai CF dan I-Geo pada sedimen 
dengan waktu pengambilan sampel bulan Mei 2016. Nilai CF untuk logam $\mathrm{Pb}$ dan $\mathrm{Cd}$ termasuk dalam kategori tingkat kategori rendah $(\mathrm{CF}<1)$ dan nilai I-Geo termasuk dalam kategori tidak tercemar $(\mathrm{I}-\mathrm{Geo}<0)$. Nilai CF logam $\mathrm{Pb}$ berkisar antara $0,0145-0,0420$ dengan rata-rata 0,0291 ; logam Cd antara 0,0340 - 0,0430 dengan ratarata 0,0374 . Sama halnya pada nilai PLI yang tergolong dalam kategori tidak tercemar sampai tercemar ringan $(0<\mathrm{PLI}<2)$, dengan rentang nilai antara $0,0235-0,0405$ dan rata-ratanya 0,0325 .

Perbedaan antara hasil pengukuran kandungan logam berat $\mathrm{Pb}$ dan $\mathrm{Cd}$ menurut waktu pengambilan sampel dapat disebabkan beberapa faktor. Kondisi di perairan sangatlah mudah berubah dan sangat fluktuatif. Dapat diketahui bahwa pada bulan Mei, di perairan sekitar Pulau Ambon sebagian besar mengalami musim timur (musim penghujan) dan bulan Desember mengalami musim barat (musim kemarau). Dari perbedaan musim tersebut dapat dihubungkan dengan adanya perbedaan kondisi di sekitar perairan Pulau Ambon. Pada musim penghuja, pergerakan di perairan sangat tinggi, begiitu sebaliknya pada musim kemarau daerah perairan akan lebih tenang dan konstan. Proses pengendapan logam berat di perairan sangat tergantung dengan pergerakan arus dan ombak di daerah perairan. Sehingga hal itu sangat mempengaruhi jumlah kandungan logam berat dalam sedimen di sekitar daerah perairan.

\section{KESIMPULAN}

Dari hasil dan pembahasan di atas dapat diambil kesimpulan sebagai berikut, sedimen yang berada dalam lokasi pengambilan sampel secara umum masuk dalam kategori belum terjadi pencemaran atau belum terkontaminasi oleh logam berat $\mathrm{Pb}$ dan $\mathrm{Cd}$. Hal tersebut mengindikasikan bahwa lingkungan sekitar pesisir Teluk Ambon Dalam atau lokasi pengambilan sampel sedimen masih aman dari kontaminasi logam berat $\mathrm{Pb}$ dan $\mathrm{Cd}$ yang berasal dari beberapa aktivitas yang terjadi di sekitar pesisir Teluk Ambon Dalam yang dilakukan oleh makhluk hidup khususnya manusia yang tinggal disekitarnya. Dilihat dari nilai Faktor Kontaminasi (CF) yang dalam penelitian memiliki rentang nilai antara 0,0065 0,0420 untuk logam $\mathrm{Pb}$ dan 0,0340 - 0,0570 untuk logam $\mathrm{Cd}$ termasuk dalam kategori tingkat kontaminasi rendah $(\mathrm{CF}<1)$. Untuk Indeks Geoakumulasi (I-Geo) didapatkan nilai kisaran antara $-7,8503--5,1584$ untuk logam $\mathrm{Pb}$ dan 5,4633 - $-4,7179$ untuk logam $\mathrm{Cd}$ yang keduanyan tergolong ke dalam kategori tidak tercemar $(\mathrm{I}-\mathrm{Geo}<0)$. Sedangkan untuk nilai Indeks Beban Pencemaran (PLI) berkisar antara
$0,0178-0,0451$ yang tergolong dalam kategori tidak tercemar sampai tercemar ringan $(0<\mathrm{PLI}$ $<2)$.

\section{DAFTAR PUSTAKA}

Ahmad, Fasmi. 2013. Distribusi dan prediksi tingkat pencemaran logam berat $(\mathrm{Pb}, \mathrm{Cd}$, $\mathrm{Cu}, \mathrm{Zn}$ Dan Ni) dalam sedimen di perairan Pulau Bangka menggunakan indeks beban pencemaran dan indeks geoakumulasi. Jurnal Ilmu Dan Teknologi Kelautan Tropis 5 (1) : 170-81.

BSN. 2004a. Sedimen - Bagian 3: Cara Uji Timbal (Pb) Secara Destruksi Asam Dengan Spektrofotometer Serapan Atom (SSA).

2004b. Sedimen - Bagian 4: Cara Uji Kadmium (Cd) Secara Destruksi Asam Dengan Spektrofotometer Serapan Atom (SSA).

CCME, Canadian Council of Ministers of the Environment. 2001. Canadian sediment quality guidelines for the protection of aquatic life: Summary tables. Canadian Council of Ministers of the Environment.

Edward. 2014. Kandungan logam berat dalam sedimen di Perairan Teluk Wawobatu, Kendari , Sulawesi Tenggara. Depik 3 (2) : 157-65.

2015. Penilaian tingkat pencemaran logam berat dalam sedimen di Perairan Pulau Morotai, Maluku Utara. Depik 4 (2) : 95-106. doi:10.13170/depik.4.2.2621.

Ismarti, Fitrah Amelia, and Ramses. 2015. Kandungan logam berat $\mathrm{Pb}$ Dan Cd pada sedimen dan kerang di Perairan Batam." Jurnal Dimensi 4 (3) : 1-8.

Mohiuddin, K. M., Y. Ogawa, H. M. Zakir, K. Otomo, and N. Shikazono. 2011. Heavy metals contamination in water and sediments of an urban river in a developing country. International Journal of Environmental Science \& Technology 8 (4) : 723-36. doi:10.1007/BF03326257.

Mulyaningsih, Th Rina, Alfian, and Sutisna. 2012. Distribusi logam berat dalam sedimen daerah aliran sungai Ciujung Banten." Jurnal Teknologi Reaktor Nuklir 14 (3) : 157-69. 
Odat, Sana'a, and Ahmed M Alshammari. 2011. Seasonal variations of soil heavy metal contaminants along urban roads: A Case study from the city of hail, Saudi Arabia. Jordan Journal of Civil Engineering 5 (4) : 581-91.

Ohello, Marselitha Trivena. 2010. Kondisi lingkungan perairan teluk ambon dalam dan hubungannya dengan perilaku masyarakat.

Permanawati, Yani, Rina Zuraida, and Andrian Ibrahim. 2013. Kandungan logam berat ( $\mathrm{Cu}, \mathrm{Pb}, \mathrm{Zn}, \mathrm{Cd}$ Dan $\mathrm{Cr}$ ) dalam air dan sedimen di Perairan Teluk Jakarta. Jurnal Geologi Kelautan 11 (1) : 9-16.

Rochyatun, Endang, and M Taufik Kaisupy. 2006. Distribusi logam berat dalam air dan sedimen di Perairan Muara Sungai Cisadane. Makara Sains 10 (1) : 35-40.

Wardhani, Eka, Dwina Roosmini, and Suprihanto Notodarmojo. 2016. Pencemaran kadmium di sedimen Waduk Saguling Provinsi Jawa Barat. Jurnal Manusia Dan Lingkungan 23 (3) : 285-94. 